\title{
Comparison of coronary risk factors and angiographic findings in younger and older patients with significant coronary artery disease
}

\author{
MOHAMMAD PARSA MAHJOOB ${ }^{1}$, SOHEILA SADEGHI ${ }^{2}$, HAMIDE FALAHATY KHANAMAN ${ }^{2}$, \\ MOHAMMADREZA NADERIAN ${ }^{3,4}$, ISA KHAHESHI ${ }^{1, *}$ \\ ${ }^{1}$ Cardiovascular Research Center, Shahid Beheshti University of Medical Sciences, Tehran, Iran \\ ${ }^{2}$ Department of Internal Medicine, School of Medicine, Shahid Beheshti University of Medical Sciences, Tehran, Iran \\ ${ }^{3}$ Non-Communicable Diseases Research Center, Endocrinology and Metabolism Population Sciences Institute, \\ Tehran University of Medical Sciences, Tehran, Iran \\ ${ }^{4}$ Cardiac Outcome Research and Education (CORE), Universal Scientific Education and Research Network \\ (USERN), Tehran, Iran
}

\begin{abstract}
Background. Coronary artery disease (CAD) is uncommon among young adults and may have certain characteristics that are different from those in older patients. The aim of the current study was to determine the risk factors of $\mathrm{CAD}$, important laboratory data and angiographic findings in young patients with CAD and to compare them with the old patients.

Methods. Patients with typical chest pain whose CAD was confirmed by coronary angiography were included in the study. These patients were divided into 2 groups: $\geq 45$ and $<45$ years old; the risk factors of CAD and angiographic findings were determined in each group and further compared.

Results. Finally, 231 patients with CAD were included in the study. Thirty-five (30.4\%) of patients younger than 45 years and $58(50.0 \%)$ aged $\geq 45$ had diabetes mellitus $(\mathrm{P}=0.002)$. Statistically remarkable differences were observed between the two groups regarding hypertension $(\mathrm{P}<0.001)$, myocardial infarction $(\mathrm{P}<0.001)$, Gensini score Median $(\mathrm{P}<0.001)$, ejection fraction in echocardiography $(\mathrm{P}<0.001)$ and fasting blood sugar in laboratory data $(\mathrm{P}=0.006)$. The older group, compared with the younger one, had higher left anterior descending (LAD) artery $(\mathrm{P}<0.001)$, right coronary artery (RCA) $(\mathrm{P}<0.001), 3$ vessel disease $(\mathrm{P}<0.001)$ and 2 -vessel disease $(\mathrm{P}=0.044)$; on the other hand, 1-vessel disease was higher in patients aged $<45(\mathrm{P}<0.001)$.

Conclusion. The risk profile and angiographic findings are different in young patients with CAD compared to older patients. Young patients with CAD tend to be male with a positive familial history, but with less diabetes or hypertension. The older patients had higher 3 vessel disease, 2-vessel disease and left anterior descending (LAD) artery and right coronary artery (RCA) involvements. In contrast, 1 -vessel disease was higher in young patients aged $<45$.
\end{abstract}

Key words: Risk Factors, Angiography, Coronary Artery Disease.

\section{INTRODUCTION}

The rate of cardiovascular diseases enhances as the number of risk factors increases [1]. Coronary artery disease (CAD) is the leading cause of death in men and women worldwide [2]. In developing countries, the age of CAD is diminishing with respect to social and economic factors [3]. Based on the reports in Iran, among the 321570 recorded annual deaths, 82307 were due to CAD [4]. Coronary artery disease is uncommon among young adults and considered an imperative problem for such patients because of its distressing consequences on their active lifestyle. It is reported that risk factors, angiographic profiles and clinical presentations could be different comparing young and old patients, having different prognostic effects in each group [5]. Proper prognosis of CAD in young adults is achieved when appropriate investtigation and treatment are established [6]. Gender difference also plays a crucial role in epidemiology, clinical manifestation, diagnosis, management and prevention of coronary artery disease [7]. Based on angiographic reports, the severity and extent of CAD were less in young patients with higher incidence of normal coronary arteries and single vessel disease in comparison to older patients [8]. Angiographic investigations have revealed that the type and number of coronary involvement may be different among younger and older patients. Additionally, positive family history of CAD, smoking, hypertension, increased body mass index (BMI), 
dyslipidemia and diabetes mellitus (DM) are among the main risk factors of $\mathrm{CAD}$ in patients younger than 45 years [9]. There are numerous risk factors for CAD in young adults and a number of atherosclerosis risk factors intensify the severity of coronary atherosclerosis in this population [10].

The aim of the current study was to specify the risk factors pertaining to $\mathrm{CAD}$, and important laboratory data and angiographic findings in young patients with $\mathrm{CAD}$ and to compare them with the older patients.

\section{MATERIALS AND METHODS}

\section{PATIENT SELECTION}

In the current cross-sectional study, we finally enrolled 231 patients with typical chest pain and significant $\mathrm{CAD}$ or visible thrombus in coronary angiography who referred to Imam Hussein hospital (Tehran, Iran) from January 2014 to February 2016; stenosis $\geq 50 \%$ in at least one major epicardial coronary artery was considered as a significant coronary artery disease which was interpreted by visual (eyeball) estimation. Patients who had not typical chest pain, significant CAD or visible thrombus in coronary angiography were excluded from the study. The enrolled patients were divided into 2 groups: $\geq 45$ and $<45$ years old; risk factors for CAD including gender, diabetes mellitus, smoking, hypertension, abnormal lipid profile and family history of CAD were further determined in each group. Positive history of opium and amphetamine consumption was also obtained through a self-report saying. The angiographic findings were specified through the use of Modified Gensini Score. The final Gensini Modified for each coronary vessel was determined by the score of all coronary vessels. Abnormal triglyceride (TG) and low density lipoprotein (LDL) were defined as $>$ $150 \mathrm{mg} / \mathrm{dL}$ and $>100 \mathrm{mg} / \mathrm{dL}$, respectively. Subsequently, the results were compared between the two groups. The study was approved by the Ethics Committee of Shahid Beheshti University of Medical Sciences and a written informed consent was obtained from each patient.

\section{STATISTICAL ANALYSIS}

The data was obtained from the transverse strength processed and analyzed by IBM SPSS statistics (Version. 23.0). The mean between groups in variables without normal distribution was compared using Mann-Whitney U test. Chi square analysis was used for group comparison and variance was checked at $95 \%$ confidence interval. Multivariate logistic regression was done using forward and backward models and the most fitted model was reported. $\mathrm{P}$ value under 0.05 indicated a significant difference between the two groups.

\section{RESULTS}

As seen in Table 1, 231 patients with CAD were included in the current cross-sectional study, including 30 females and 85 males in $<45$ years old and 46 females and 70 males in $\geq 45$ year old $(p=0.02)$. DM and hypertension were significantly less prevalent in younger patients compared to older patients ( $\mathrm{p}=0.002$ and $\mathrm{p}<0.001$, respectively). As seen, $20.9 \%$ in $<45$ years old and $7.8 \%$ in $\geq 45$ years old group have a positive family history of CAD $(\mathrm{p}=0.004)$. No significant differences were detected regarding smoking and opium addiction between the two groups $(\mathrm{p}=0.815)$. In contrast, amphetamine addiction was borderline higher in younger group $(p=0.054)$. Myocardial infarction was significantly higher in older patients in comparison with younger patients $(\mathrm{p}=0.001)$. No notable difference was observed on abnormal serum low density lipoprotein and triglyceride levels. The distinction, however, was significant concerning fasting blood sugar (FBS) $(\mathrm{P}=0.006)$. Gensini score mean was significantly higher in $\geq 45$ years old; $6.62(\mathrm{SD}=3.93)$ in comparison with 4.21 $(\mathrm{SD}=2.57)$ in younger subjects ( $\mathrm{p}$ value $<0.001)$.

As seen in Table 2, significant differences were observed in LAD and RCA territory involvement $(\mathrm{p}<0.001)$. No significant differences were observed in the LCX territory involvement $(\mathrm{p}=$ 0.261 ). In this study, older patients were more likely to have 3-vessel disease $(\mathrm{p}<0.001)$ and 2-vessel disease $(\mathrm{p}=0.04)$; but younger patients were more likely to have single-vessel disease $(p<0.001)$. No differences were detected for visible thrombus in coronary angiography between the two groups $(\mathrm{p}=0.80)$.

Table 3 shows the results of multivariate logistic regression for occurrence of myocardial infarction in patients younger and older than 45 years. In younger patients, opium addiction and abnormal LDL were positive predictors and positive family history was negative predictor for MI, while in older subjects, there was no independent predictor. 
Table 1

Basic demographic and laboratory information of subjects in this study

\begin{tabular}{|c|c|c|c|}
\hline & $\begin{array}{c}<45 \text { years } \\
\mathrm{N}(\%) \text { or mean }(\mathrm{SD})\end{array}$ & $\begin{array}{c}\geq 45 \text { years } \\
\mathrm{N}(\%) \text { or mean }(\mathrm{SD})\end{array}$ & $P$ value \\
\hline Male & $85(73.9)$ & $70(60.3)$ & 0.02 \\
\hline Diabetes Mellitus & $35(30.4)$ & $58(50.0)$ & 0.002 \\
\hline Hypertension & $22(19.1)$ & $54(46.6)$ & $<0.001$ \\
\hline Positive FH & $24(20.9)$ & $9(7.8)$ & 0.004 \\
\hline Smoking & $37(32.2)$ & 39 (33.6) & 0.815 \\
\hline Opium Addiction & $15(13)$ & $24(20.7)$ & 0.121 \\
\hline Amphetamine Addiction & $6(5.2)$ & $1(0.9)$ & 0.054 \\
\hline MI & $16(13.9)$ & 37 (31.9) & 0.001 \\
\hline Abnormal LDL (> $100 \mathrm{mg} / \mathrm{dL})$ & $16(13.9)$ & $20(17.2)$ & 0.486 \\
\hline Abnormal TG (> $150 \mathrm{mg} / \mathrm{dL})$ & $19(16.5)$ & $25(21.6)$ & 0.330 \\
\hline Abnormal HDL ( $<50$ mg/dL) & $20(17.4)$ & $7(6.0)$ & 0.007 \\
\hline Gensini score & $4.21(2.57)$ & $6.62(3.93)$ & $<0.001$ \\
\hline FBS, mg/dL & $110.19(40.41)$ & $125.28(55.40)$ & 0.006 \\
\hline
\end{tabular}

Abbreviations: dL: Deciliter; EF: Ejection fraction; FBS: Fasting blood sugar; FH: Family history; HDL: Highdensity lipoprotein, LDL: Low-density lipoprotein; mg: Milligram; MI: Myocardial infarction; N: Number; SD: Standard deviation; TG: Triglyceride.

Table 2

Angiographic findings of the patients with CAD in 2 groups of subjects

\begin{tabular}{lccc}
\hline & $\begin{array}{c}<\mathbf{4 5} \text { years } \\
\mathbf{N}(\%)\end{array}$ & $\begin{array}{c}\geq \mathbf{4 5} \text { years } \\
\mathbf{N}(\boldsymbol{\%})\end{array}$ & P value \\
\hline LAD involvement & $61(53)$ & $97(83.6)$ & $<0.001$ \\
LCx involvement & $53(46.1)$ & $62(53.4)$ & 0.263 \\
RCA involvement & $39(33.9)$ & $64(55.2)$ & $<0.001$ \\
3-VD & $6(5.2)$ & $31(26.7)$ & $<0.001$ \\
2-VD & $25(21.7)$ & $39(33.6)$ & 0.044 \\
1-VD & $82(71.3)$ & $43(37.1)$ & $<0.001$ \\
Thrombus & $7(6.1)$ & $8(6.9)$ & 0.803 \\
\hline
\end{tabular}

Abbreviations: LAD:left anterior descending; LCx: left circumflex; RCA: right coronary artery; 3-VD: 3-vessel disease; 2-VD: 2-vessel disease; 1-VD: single-vessel disease.

Table 3

Multivariate logistic regression for occurrence of myocardial infarction in patients younger and older than 45 years

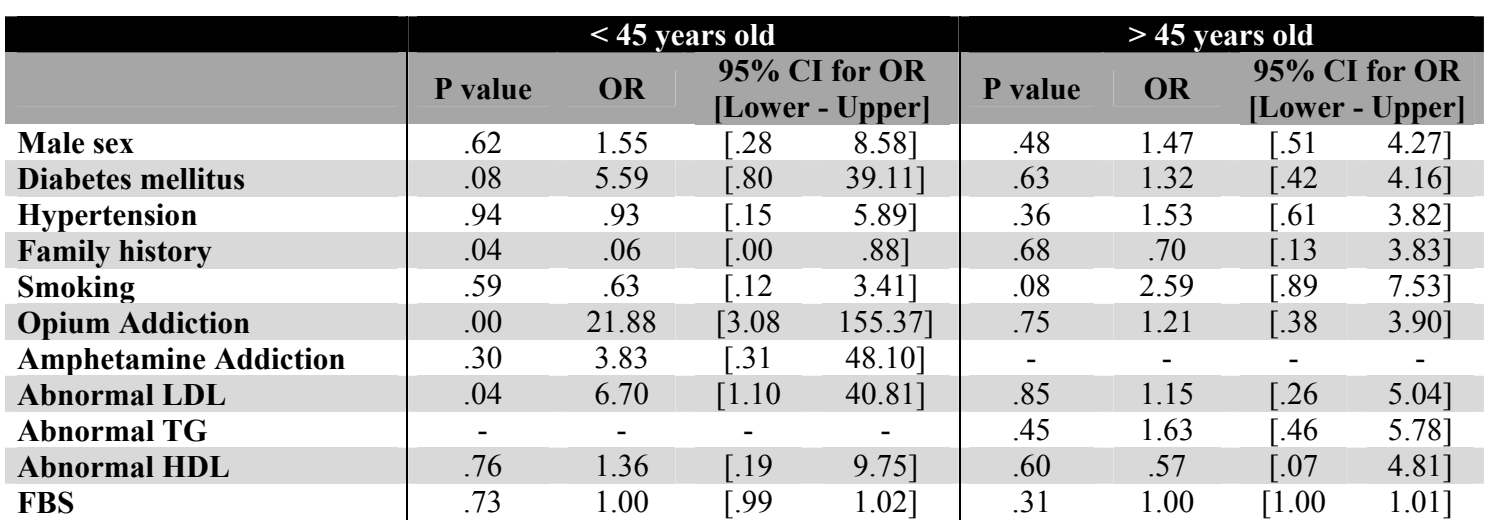

Abbreviations: CI: Confidence interval; FBS: Fasting blood sugar; FH: Family history; HDL: High density lipoprotein; LDL: Low density lipoprotein; S.E.: Standard error; TG: Triglyceride.

\section{DISCUSSION}

Significant coronary artery disease (CAD) is a challenging issue particularly in the young and active patients. During past decade, concerns have increased about significant $\mathrm{CAD}$ in young population and the factors that may have a prominent role; moreover, the patterns of coronary involvement may be different in young adults in comparison to old patients.

The present study determined the pattern of risk factors and angiographic findings distribution among two groups, one aged 45 or more and the other less than 45 . It should be noted that the 
number of males was higher in the younger group, while females were more dominant in the older one. Based on the results, more patients had DM in $\geq$ 45 years old compared to $<45$ years group. Previous studies showed that DM entails a 5-fold increase in the risk of CAD for females while for diabetic males the augment is 2-fold [1]. It should be emphasized that the complex role of DM in the young patients should be better elucidated in the future large investigation. HTN was higher in the older group and it is associated with adverse changes in the structure and function of arterial walls leading to left ventricular hypertrophy and ischemia [11]. Similar to DM, comprehensible role of HTN in the young population is challenging and needs to be profoundly explored. The positive family history of CAD was higher in the young population; however, in multivariate analysis it showed a reverse role, it means that positive family history may not have a role in these young patients. This finding is contrasting to the previous result which highlighted the positive role of family history of CAD. In one study, $39 \%$ of the participants were reported to have a positive family history of premature CAD [11]. In another investigation, children born of parents with premature coronary heart disease tended to be more susceptible to LDL, HDL and TG abnormalities [12]; moreover, fasting blood sugar was higher in the older group (46\%) than in the other (28\%). Obesity and DM are more observed in these children [12]. According to certain research, close associations exists between traditional risk factors and the risk of CAD in young adults [5, 13]. Based on the results of the current study, MI was higher in $\geq 45$ years group. Arterial abnormalities are frequently reported in $<45$ patients with MI [14]. In patients with a family history of premature coronary artery disease, the probability of finding coronary artery disease has been reported to be higher [15]. A detailed history of traditional cardiac risk factors of CAD reveals that men younger than 55 years and women under 65 years of age are more bound to have positive family history of CAD [6]. In a study on CAD in 45 young patients in Keshmir, DM, HTN and hyperlipidemia were observed in $12 \%, 40 \%$ and $48 \%$ of them, respectively [5]. In a recent study on the risk factors of CAD in Palestinian patients undergoing coronary angiography the most remarkable risk factors of CAD were lifestyle, LDL/HDL ratio, positive family history, hypertension, DM and smoking [16]. In a study with the objective of comparing the risk factors and coronary angiographic profiles in younger $(<40$ years old) and older patients ( $\geq 40$ years old), Islam et al. reported smoking $(63.3 \%)$, and family history of coronary artery disease $(21.7 \%)$ were more common in the younger group, whereas HTN $(65.0 \%)$ and DM (36.7\%) were the more dominant factors in older patients [17]. Based on genetic studies, -344T/C polymorphism of CYP11B2 gene affects CAD [18]. Chu et al. reported that there existed a relationship between genetic polymorphism of cholesteryl ester transfer protein and endothelial nitric oxide synthase with the risk of CAD [19]. The role of positive family history of CAD is an undeniable dilemma that requires to be studied and explored in detail regarding various key factors.

We observed that pattern of involved vessel was different between younger and older patients. Based on the angiographic results, 2-vessel disease and 3-vessel disease and LAD and RCA involvement were more frequent in older patients, while single-vessel disease was observed more in the younger group. In a study, it was reported that single-vessel disease involvement was more common in the young patients and that the LAD artery was the most commonly involved vessel by occlusive lesion in the young patients, and 3-vessel disease was more prominent among the elderly [20]. In another investigation consisting of 112 Iranian patients, $51(45.5 \%)$ were aged $<50$ and $61(54.5 \%)$ were aged $>50$ years old; LCX involvement was $54.9 \%$ in $<50$ years old while $54.1 \%$ in $>50$ years old, RCA involvement was $54.9 \%$ in $<50$ years old whereas $54.1 \%$ in $>50$ years old and LAD involvement was $54.9 \%$ in $<50$ years old versus $54.1 \%$ in $>$ 50 years old. There were no statistical significant differences regarding coronary arteries involvement and the number of vessel disease between $<50$ and $>50$ years old patients. Left anterior descending artery was the most commonly involved vessel followed by RCA and LCX in both groups [3]. Another study reported that LAD was the most commonly involved vessel followed by RCA and LCX in both young and old patients [21]. In our study, the LAD involvement was lower in younger $(53 \%)$ than in the older patients $(83.5 \%)$. Young adults are characterized by a less extensive coronary disease or 1VD form [22]. In younger patients, positive family history plays an important role as a risk factor for IHD. Based on the reports, DM and HTN were the more common risk factors among older patients, yet they were less common in young adults [23].

In another comprehensive study, male sex, smoking, hypertension, hyperlipidemia and positive 
family history of coronary artery disease were associated with the premature CAD (male $<45$ years and female $<55$ years); Moreover, premature CAD had upper rates of hyperlipidemia, positive family history of coronary artery disease and single vessel disease [24]. This study shows some contrasts with our current results regarding to smoking and hyperlipidemia which were not significantly different between the younger and older groups and hypertension which was significantly higher in the older patients.

In one more investigation, the population of young patients with CAD is predominantly male, and the most important CAD risk factors in young adults were dyslipidemia, smoking, and overweight/ obesity. Furthermore, single vessel disease and STelevation myocardial infarction presentation were prominent in young patients [25]. Similar to these results, single vessel disease was predominant in the young patients aged $<45$.

As the last point, Amphetamine addiction was borderline prominent in younger group of our current study. This finding is so crucial for clinicians who are faced with the young patients with the complaint of typical chest pain in emergency units.
Internists and clinicians should be familiar with the potential cardiac effects of Amphetamines and recreational drugs which are abused particularly in younger adults [26-28].

This study with its relatively moderate sample size cannot answer all questions and determine all differences. Future investigations with large sample sizes are recommended to reveal more detailed data.

\section{CONCLUSION}

The risk profile and angiographic findings are different in young patients with CAD compared to older patients. Young patients with CAD tend to be male with a positive familial history, but with less diabetes or hypertension. The older patients had higher 3 vessel disease, 2-vessel disease and left anterior descending (LAD) artery and right coronary artery (RCA) involvements. In contrast, 1-vessel disease was higher in young patients aged $<45$.

Conflict of Interest: The authors declare that there is no conflict of interest.

Introducere. Boala coronariană acută (BCA) nu este caracteristică pacienților de vârstă tânără şi prezintă anumite caracteristici diferite de populația bătrână. Obiectivul studiului a fost de a evidenția caracteristicile BCA la pacienții tineri şi de a le compara cu cele observate la pacienții vârstnici cu BCA.

Materiale şi metode. Au fost incluşi pacienți cu durere precordială şi cu diagnosticul de BCA confirmat angiografic. Pacienții au fost împărțiți în 2 grupuri $\geq$ 45 şi $<45$ de ani. Factorii de risc pentru BCA şi caracteristicile angiografice au fost măsurate şi comparate între cele două grupuri.

Rezultate. Au fost incluşi 231 de pacienți. 35 de pacienți (30.4\%) mai tineri de 45 de ani şi 58 de pacienți (50\%) peste 45 de ani au avut diabet zaharat $(p=$ 0.002). Au fost găsite diferențe semnificative privind cele două grupuri din punctul de vedere al hipertensiunii, a infarctului miocardic, a scorului median Genisini, a fracției de ejecție ecocardiografice (toate cu $p<0.001$ ) şi glicemie a jèun ( $p=$ 0.006). Pacienții în vârstă au avut mai frecvent afectate coronarele anterioare descendente stângi, corornarele drepte, boală bi şi trivasculară. Pacienții mai tineri au avut însă mai frecvent afectarea unui singur vas.

Concluzii. Factorii de risc şi caracteristicile angiografice sunt diferite la pacienții tineri cu BCA comparativ cu pacienții mai în vârstă. Pacienții tineri cu $B C A$ au o tendință de a fi mai degrabă de gen masculin, cu istoric familial prezent dar cu o frecvență mai redusă a diabetului zaharat sau a hipertensiunii. Pacienții mai în vârstă au avut mai frecvent afectate coronarele anterioare descendente stângi, coronarele drepte, boală bi ş̧i trivasculară. Pacienții mai tineri au avut însă mai frecvent afectarea unui singur vas.

Correspondence to: Isa Khaheshi, MD, Cardiovascular Research Center,

Shahid Beheshti University of Medical Sciences, Tehran, Iran

Tel: +982122083106

Email: isa.khaheshi@gmail.com 


\section{REFERENCES}

1. ABED Y, JAMEE A. Characteristics and risk factors attributed to coronary artery disease in women attended health services in Gaza-Palestine observational study. World J Cardiovasc Dis. 2015; 5(01):9.

2. ROGER VL, GO AS, LLOYD-JONES DM, BENJAMIN EJ, BERRY JD, BORDEN WB, et al. Executive summary: heart disease and stroke statistics--2012 update: a report from the American Heart Association. Circulation. 2012; 125(1):188-97.

3. MOSHAR S, NAJIBPOUR R, MOHSENIKIA M, BAYESH S, RAD KV, RAHIMI N. Comparison of angiography findings in iranian patients younger and older than 50 years underwent coronary angiography in Boo-Ali hospital: A cross-sectional study. Thrita. 2016; 5(1).

4. AMANI F, KAZEMNEJAD A, HABIBI R, HAJIZADEH E. Pattern of mortality trend in Iran during 1970-2009. J of Gorgan Univ of Med Sci. 2011; 12(4).

5. HASSAN Z, FAROOQ S, NAZIR N, IQBAL K. Coronary artery disease in young: A study of risk factors and angiographic characterization in the Valley of Kashmir. Int J of Sci and Res Pub. 2014; 4(7):1.

6. SCHOENENBERGER AW, RADOVANOVIC D, STAUFFER J-C, WINDECKER S, URBAN P, NIEDERMAIER G, et al. Acute coronary syndromes in young patients: presentation, treatment and outcome. Int J Cardiol. 2011; 148(3):300-04.

7. PANDURANGA P, SULAIMAN K, AL-ZAKWANI I. Acute coronary syndrome in oman: results from the gulf registry of acute coronary events. Sultan Qaboos Univ Med J. 2011; 11(3):338.

8. REZENDE PC, HUEB W, GARZILLO CL, LIMA EG, HUEB AC, RAMIRES JAF, et al. Ten-year outcomes of patients randomized to surgery, angioplasty, or medical treatment for stable multivessel coronary disease: effect of age in the Medicine, Angioplasty, or Surgery Study II trial. J Thorac Cardiovasc Surg. 2013; 146(5):1105-12.

9. NADEEM M, AHMED SS, MANSOOR S, FAROOQ S. Risk factors for coronary heart disease in patients below 45 years of age. Pak J Med Sci. 2013; 29(1):91.

10. SOZZI FB, DANZI GB, FOCO L, FERLINI M, TUBARO M, GALLI M, et al. Myocardial infarction in the young: a sex-based comparison. Coron Artery Dis. 2007; 18(6):429-31.

11. EGRED M, VISWANATHAN G, DAVIS G. Myocardial infarction in young adults. Postgrad Med J. 2005; 81(962):741-45.

12. BERENSON GS, SRINIVASAN SR, BAO W, NEWMAN WP, TRACY RE, WATTIGNEY WA. Association between multiple cardiovascular risk factors and atherosclerosis in children and young adults. N Engl J Med. 1998; 338(23):1650-56.

13. EZHUMALAI B, JAYARAMAN B. Angiographic prevalence and pattern of coronary artery disease in women. Indian Heart J. 2014; 66(4):422-26.

14. LIAO Y, COOPER RS, MENSAH GA, MCGEE DL. Left ventricular hypertrophy has a greater impact on survival in women than in men. Circulation. 1995; 92(4):805-10.

15. ZIMMERMAN FH, CAMERON A, FISHER LD, GRACE N. Myocardial infarction in young adults: angiographic characterization, risk factors and prognosis (Coronary Artery Surgery Study Registry). J Am Coll Cardiol. 1995; 26(3):654-61.

16. ELJEDI A, MUSHTAHA M. Risk factors of coronary artery disease in Palestinian patients undergoing coronary angiography: a case-control study. 2015.

17. ISLAM KN, CHOWDHURY AW, KHANDAKER AH, SABAH NKM, AMIN M, KABIR SR, et al. Comparison of different risk factors and coronary angiographic profile in younger and older patients with ischeamic heart disease. 2015.

18. ANG C, CHAN K. A Review of Coronary Artery Disease Research in Malaysia. Med J Malaysia. 2016; 71(Suppl 1):42-57.

19. CHU WC, AZIZ AFA, NORDIN AJ, CHEAH YK. Association of cholesteryl ester transfer protein and endothelial nitric oxide synthase gene polymorphisms with coronary artery disease in the multi-ethnic Malaysian population. Clin Appl Thromb Hemost. 2016; 22(6):581-88.

20. NAFAKHI HAF. Coronary angiographic findings in young patients with coronary artery disease. Int J Collab Res Intern Med Public Health. 2013;5(1):48-53.

21. PRADEEP K, HARITHA P, KRISMAN N, UMESAN C, JOSEPH P, CHANDRA K. Comparison of coronary artery profile in young and old patients with coronary artery disease and its correlation with coronary risk factors. Indian Heart J. $2004 ; \mathbf{5 6}: 412$.

22. FARNAZ SEPASI M. Risk factors, clinical manifestations and outcome of acute myocardial infarction in young patients. $\mathrm{J}$ Cardiovasc Thorac Res. 2010; 2(1):29-34.

23. SRICHARAN K, RAJESH S, RASHMI MH, MEGHANA H, BADIGER S, MATHEW S. Study of acute myocardial infarction in young adults: risk factors, presentation and angiographic findings. J Clin Diagn Res. 2012; 6(2):257-60.

24. MOHAMMAD AM, JEHANGEER HI, SHAIKHOW SK. Prevalence and risk factors of premature coronary artery disease in patients undergoing coronary angiography in Kurdistan, Iraq. BMC Cardiovasc Disord. 2015; 15(1):155.

25. MAROSZYŃSKA-DMOCH EM, WOŻAKOWSKA-KAPŁON B. Clinical and angiographic characteristics of coronary artery disease in young adults: a single centre study. Kardiol Pol. 2016; 74(4):314-21.

26. PARATZ ED, CUNNINGHAM NJ, MACISAAC AI. The cardiac complications of methamphetamines. Heart Lung Circ. 2016; 25(4):325-32.

27. KHAHESHI I, MAHJOOB MP, ESMAEELI S, ESLAMI V, HAYBAR H. Simultaneous thrombosis of the left anterior descending artery and the right coronary artery in a 34-year-old crystal methamphetamine abuser. Korean Circ J. 2015; 45(2): $158-60$.

28. YEO K-K, WIJETUNGA M, ITO H, EFIRD JT, TAY K, SETO TB, et al. The association of methamphetamine use and cardiomyopathy in young patients. Am J Med. 2007; 120(2):165-71.

Received August 19, 2017 